\title{
S19 - La simulación como herramienta en educación médica para la seguridad del paciente
}

\author{
Luis A. Moya-Barquín \\ Escuela de Estudios de Posgrado, Facultad de Ciencias Médicas, Universidad de San Carlos de Guatemala. \\ *Autor al que se dirige la correspondencia: sistemaluismoya@gmail.com
}

\section{Resumen}

T a simulación es una metodología que introduce el Crew Resource Management en la resolución de escenarios _complejos, dinámicos, de alta incertidumbre, en lugares de recursos limitados incluyendo el tiempo basado en un equipo de alto rendimiento. La formación tradicional ha limitado que el sujeto en la educación tenga inhibición del liderazgo, reducción de la capacidad de toma de decisiones y con menos capacidad en la autocritica e intercrítica. Existen modelos en los que un escenario es basado en un objetivo y por medio de un checklist se puede llegar a acreditar el cumplimiento de las partes del proceso además de poder llevar por rubrica el desarrollo de las competencias. Se analizan tres tesis en las cuales se evidencia la utilidad en estudiantes de pregrado y postgrado; donde incluso la antigüedad en médicos y enfermería no son factores de mejor desempeño. La simulación puede servir para auditar el conocimiento explicito y permite identificar la brecha para la mejora continua. Se ha dicho que primero es importante no hacer daño en el principio de beneficencia pero debe de mostrarse los caminos para aplicar la Lex Artis. Por ello agregamos a Primun non nocere secundum fiat Lex Artis as primum as celeriem (Primero no hacer daño y segundo haz la Lex Artis tan rápido como lo primero)

Palabras claves: Lex artis, competencias médicas, desempeño médico, formula Utstein

\begin{abstract}
$\mathrm{M}$ edical simulation is a useful tool that uses Crew Resource Management in apporach of complex scenarios, dinamic, high uncertainbility in places with lack of resources as time sensitive in high performance teams. The tradicional education makes lower empowerment and leadership, lower decision making capabilities and lower insight and objetive analysis. An objective based scenario and checklist follow up can be useful to endorse of competences in the performance rubrica. Three research studies show the useful of medical simulation in undergraduate and postgraduate to express even seniority in doctors and nurses have not better performance. Medical simulation can be used to evaluate the explicit knowledge and identifiy the gap to improvement. It is common first do not harm, but based in beneficience we need know the pathways to make Lex Artis. For this we add Primum non nocere secundum fiat Lex Artis as primum as celeriem (first do not harm second make Lex Artis as fast as the first one )
\end{abstract}

Keywords: Lex artis, medical competences, medical performance, utstein formula 